\title{
The Impact of Digitalization of Marketing and Consumer Purchasing Power as an Intervening Towards Intention to Buy Product in Store-Based Retail Store
}

\author{
Bob Foster, Fitriani Retya
}

\begin{abstract}
The phenomenon of declining purchasing power in Indonesia consumers and the rise of digital marketing make new assumption that the closing of retail outlets in several big cities in Indonesia is caused by the rise of online marketing and the declining of purchasing power. The debate of economists and related government bureaus on whether the purchasing power and digital marketing is causing the shift of consumers shopping online so that retail outlets close or other causes. The existing data needs to be investigated more deeply whether this phenomenon is due to a decrease in income or trend of online shopping cause or both variables. This research aims to know the impact of digitalization in marketing toward intention to buy with consumer purchasing power as intervening, hundred sample taken in store-retail consumer in Bandung city, Indonesia. This research uses Partial Least Square (PLS) for data analysis, explanatory method and simple random sampling. The results of data testing show that digital marketing does not give a direct impact on intention to buy and purchasing power plays a significant role as an intervening variable.
\end{abstract}

Index Terms: Costumer, Digital Marketing, Purchasing Power, Intention to Buy, Retail Store.

\section{INTRODUCTION}

Retail industry in Indonesia is facing a complex problem. One by one the retail industry players began to discontinue its retail outlet operations. Until now there are some retail business actors who closed out their business outlets. The issue of economic slowdown or the weakening of people's purchasing power becomes one of the causes. The government itself denied a decline in public purchasing power. Minister of National Development Planning or Head of National Development Planning Agency (Bappenas), Bambang Brodjonegoro said what happens today is the change in consumption patterns of society, seen from the behavior of people who prefer to shop for household needs at stores near home than in big supermarkets. Based on macro data there is no decrease in people's purchasing power. Indonesia's household consumption growth in the second quarter of 2017 reached 4.95 percent, up 0.05 percentage points compared to the first quarter of 2017 of 4.9 percent. Refers to consumption-related macro data, there is clearly no weakening of purchasing power, either consumption per type of goods or per capita all showing growth. The weakening of purchasing power is not reflected in macroeconomic data [1].

In contradiction with data result by the Indonesian Ministry of National Development Planning the phenomena indicate otherwise, judging from the statistics, the growth rate of household consumption did show symptoms of slowing. Household consumption is considered the most appropriate indicator to measure people's purchasing power. Based on the Consumption and Community Purchasing Power report as of August 2017, the Fiscal Policy Office of the Ministry of Finance also mentioned that there is a slowing growth in per capita consumption in upper middle income communities throughout 2017. Decrease in purchasing power is not only visible on statistical figures, but also facts on the ground. In recent months, many modern shopping centers are lack of visitors.

Another cause of decreasing and closing retail outlets in Indonesia is the pattern shifting of people spending in Indonesia from conventional to online systems or electronic commerce as the massive development of the digital world. In 2011, Mallin proposed a digital marketing uses the development of the digital world to do advertising that is not touted directly but has a powerful effect [2]. In 2012, Hidaya and Tobing present a marketing with digital marketing has a very strong link in Indonesia [3]. If someone starts to explore the business of marketing over the internet he will soon find it that instead of looking for some customers, he will now have the ability to reach millions of customers from a more specific global and group approach as well as from customers closer to him as well, more widespread appeal than its previously owned business. He can use social media as a market, and also has a targeted market.

Another research support that result, Meyliana in an earlier study entitled "E-marketing Strategy Analysis and Implementation on Rental Company" said e-marketing is part of e-commerce which is a trading system through the internet, where the internet will continue to provide up to date properties, then the company can provide product information services offered clearly and easily [4]. Due to previous research and field fact in Indonesia both consumer and producer prefer use online retail than in store retail because flexibility, comfort and cost matter. Due to cost matter, certainly related to the ability of consumer financial or purchasing power.
Revised Manuscript Received on April 25, 2019.

Bob Foster, Business and Informatic University, 40285, Indonesia.

Fitriani Retya, Widyatama University, 40125, Indonesia. 


\section{The Impact of Digitalization of Marketing and Consumer Purchasing Power as an Intervening Towards Intention to Buy Product in Store-Based Retail Store}

From the background of previous research and the phenomenon of problems in the field then the author performs the analysis through "The impact of digitalization of marketing and consumer purchasing power as an intervening towards intentions to buy product in store-based retail store".

\section{LITERATURE REVIEW}

\section{A. Form and Dimension of Purchasing Power}

In 2016, Pawengan described a public purchasing power is the ability of the community as a consumer to buy goods or services needed [5]. Public purchasing power is characterized by an increase or decrease, where purchasing power increases if higher than last period while decreasing purchasing power is characterized by higher purchasing power from the previous period. According to the statistics center of Indonesia in the official website bps.go.id purchasing power is the ability of people in spending money in the form of goods or services. To measure consumers' purchasing power, the macroeconomic approach is used. The theory of Sritua measures purchasing power by socio economic welfare through social conditions and economic conditions as measured by the overall community level of living index [6]. Index comprehensive life rates are calculated using indicators, including: a) Income, b) Housing condition, c) Education, d) Health, e) Retail spending or needs, f) Increase in the price of goods g) Political participation of the community. Another theory conduct by Salvatore, this theory expressed the theory of microeconomic prosperity. Economic theory welfare studies of the conditions under which the solution of the equilibrium model is accomplished general can be said optimally. This requires, inter alia, the optimal allocation of factors of production among consumers the allocation of production factors is said to be optimal if the production process cannot be arranged again in such a way as to raise the output of one or more commodities without necessity reducing output of other commodities [7].

\section{B. Form and Dimension of Digital Marketing}

In 2009, Smith et. al described digital media refers to electronic media that disseminate information in digital formats [8]. This includes any media available via computers, cell phones, smart phones, or other digital devices such as digital outdoor signs. Digital marketing is a promotion using Internet for the purpose of effectiveness marketing messages. Digital or online advertising has undergone phenomenal growth since its inception in 1994, the other research by [8], when people read an online advertisement; they are more likely to buy online. An advertising banner on the Internet can level the playing field between large and small companies. In contrary, another research confirms that consumers have developed negative attitudes toward digital marketing that they consider intrusive [9]. In 2001, Chatterjee conduct research that concern in escalating over consumers developing negative perceptions of digital advertising, mainly due to intrusive messages being delivered to their gadget devices, consumer don't like messages that are distracting, disturbing, forced, or interfere with their work such as pop-up ads [10]. In 2002, Eun Young Kim sets four dimensions Digital Marketing [11]. Four dimensional digital marketing is an independent variable that helps success business as a dependent variable. The four dimensions which is known as follows: a) Interactive, b) Incentive Program, c) Site Design, d) Cost.

\section{Form and Dimension of Intention to Buy}

Buying interest is defined as the possibility of a consumer intending to buy a product. Consumer buying interest in a product is strongly influenced by several factors [12]. Interest is part of the perceived value that will affect the willingness to buy (buying interest). Perceived value consists of Perceived Quality and Perceived Sacrifice, which is the dimension of Perception of Price [13]. The intention of buying or buying intention is a decision-making process undertaken by the consumer before making a purchase of products offered or required by the consumer [14]. The tendency of consumers to buy a brand or take action-related with purchases measured by the level of likelihood consumers make purchases [15]. In 2017, Hakim et. al proposed a buying interest can be identified through indicators as follows: 1) Transactional interest, 2) Referential interest, 3) Preference interests, 4) Interest explorative [16].

\section{THEORETICAL FRAMEWORK}

Previous research conducted by Janah et. al (2016) entitled "The Effect of Raw Rubber Price Decreasing Towards Community Purchase Power Buying" in Pasir Jaya village, Riau Province, Indonesia [17]. The results of the regression analysis indicate there is a very strong and significant correlation between go down price of raw rubber with power of buy society at traditional market in Pasir Jaya village that is equal to 0,529 or by $52,9 \%$. When the cost of the source of income lower than usual people tend to be selective at buying their needs. In line with this research, another research conduct by Wahyutyasto titled "The Influence of Mobile Marketing Toward Purchase Intention (at California Fried Chicken (CFC) Store Telkom University, Bandung)" shows result that mobile marketing effect on consumer buying interest California Fried Chicken Store University Telkom [18]. Based on the calculation of coefficient of determination (R2) can know the amount of influence mobile marketing (X) against buying interest (Y) is $29.9 \%$. While the remaining $70.1 \%$ influenced by other factors not examined in this study such as product image, consumer attitude. In 2017, Wiyadi et al conduct researched titled "Variables That Influence Power Ability Buy House", this research examines variables of purchasing power that affect the ability to buy a house in Malang City, Eat Java, Indonesia [19]. The result of the research shows that loan variable PUMP-KB PT. Jamsostek (Persero), another source of advances, the ratio of dependence in the family have a significant effect on the ability to buy a house in the participants of PT. Jamsostek (Persero) Malang. The results of previous study also show that Digital Marketing does not always have a strong enough effect on intention to buy. From this perspective that cost, incentive program, site design and interactive not always impact someone willingness, whether it concerns 
performance or buying interest. In this research is combine phenomenon in Indonesia about the rise of digital marketing, weakening of purchasing power and decreasing number of retail store caused by shifting in consumer behavior that assume buying online with many discount offer and lower cost increase their purchase power and effect the intention to buy in store-based retail store depict in research model below.

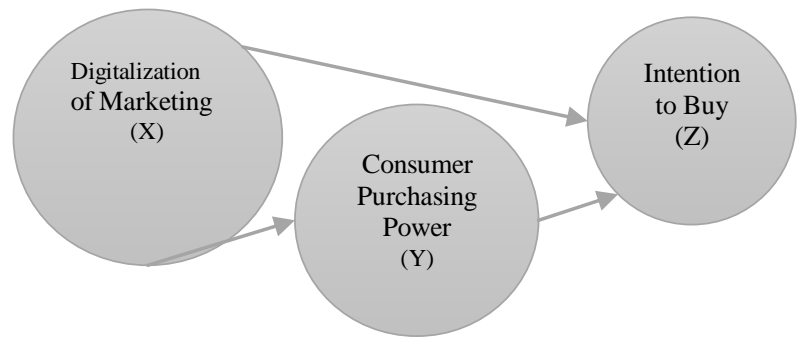

Fig. 1. Research Model

\section{METHODOLOGY}

All elements, sharing some common characteristics, which comprise the universe for the purpose of the research problem [20]. Population within this research is consumer store-based retail in Indonesia, that is the consumer at various 5 top retail stores in Indonesia. The sample is a subgroup of the whole population is selected for data collection. A researcher has to consider data analysis techniques used within the study when determining the study sample size, within this respect, the most demanding proposed data analysis technique for this study is partial least square method [20]. The method chosen was non-probability sampling because a sampling list was not accessible. Non-probability sampling that suitable for this research is quota sampling. Quota sampling can be described as a two-stage judgemental process. Stage one involves developing a control category, or a quota, of the population elements. In the second stage, judgemental or convenience sampling is then used for the selection of the sample elements Respondent as sample in this research is all consumer of top five regional and national supermarkets in Bandung city, West Java the rank itself given based on USDA report (Global Agriculture Information Network).

Number of samples used is 100 respondents, and then the number of questionnaires will be distributed to 100 respondents. The lists of supermarket that represent population are: 1) Yogya/Griya Supermarket, 2) Borma Toserba, 3) Superindo Lion, 4) Carrefour/Transmart, 5) Hypermart. Each supermarket will be represented by 20 respondent or customer, so the value for 5 supermarkets will be 5 x $20=100$ respondents in Bandung City. For data analysis, validity, reliability and hypothesis testing used in this research is partial least square assisted by XL Stat software for data processing. Partial Least Square (PLS) is a part of Structural Equation Modeling (SEM). This PLS method is a new method that has been widely used in research because it can use the number of samples less [21].

\section{OPERATION VARIABLES}

\section{A. Digital Marketing}

1) Cost, is one of the promotional techniques possess a high level of efficiency can reduce transaction costs and time.

2) Incentive Programs are programs that excite ones to become an advantage in every promotion made. These programs also expected to provide more value to the company.

3) Site Design, is an attractive look inside digital media marketing that can deliver positive value for the company.

4) Interactive, is a relationship between companies with consumers who can provide info and can be well received and clear.

\section{B. Consumer Purchase Power (y)}

A. Income, is an individual or business earnings in exchange for providing a good or service or through investing capital.

B. Housing conditions, is simply the quality of the internal and external structure of a dwelling and aspects of the internal environment.

C. Education, is respondent educational background.

D. Health, is health level and health insurance ownership.

E. Retail spending or needs is the level purchases of finished goods and services by consumers and businesses.

F. Increase in the price of goods, is the level of price escalation or increasing per period.

G. Political participation of the community, is the number of participation in political even held by government.

\section{Intention to Buy (z)}

1) Transactional interest, namely the tendency of someone to buy the product.

2) Referential interest, namely the tendency of a person to reference the product to others.

3) Preferential interests, i.e. interests that describe the behavior of someone who has a primary preference for the product, where this preference can only be replaced if something happens with its preferred product.

4) Interest explorative, the interest that describes the behavior of a person who is always looking for information about the products of interest and seeks information to support the positive characteristics of the product in question. 
The Impact of Digitalization of Marketing and Consumer Purchasing Power as an Intervening Towards Intention to Buy Product in Store-Based Retail Store

\section{HYPOTHESIS TESTING}

The hypothesis to be tested and proven in this research is related with the presence/absence of the influence of independent variables. Hypothesis testing performed is testing the null hypothesis (Ho) and alternative Hypothesis:

(Ha). The null hypothesis (Ho) states the correlation coefficient is insignificant, while the alternative hypothesis (Ha) states that the correlation coefficient means/significant. Formulation of the Null Hypothesis (Ho) and Alternative Hypothesis (Ha). For hypothesis testing with PLS method ( $\beta$, $Y$, and $\lambda$ ) processed by Bootstrap resampling developed by Geisser \& Stone. The test statistic used is t statistic or $t$ test. The application of the resampling method, allowing the enactment of distributed free data does not require the assumption of normal distribution, nor does it require large samples (recommended minimum sample 30). Testing is run by t-test, when obtained by $p$-value $<>$. The researcher proposed the statistical hypothesis as follows:

1) Ha1: $r \neq 0$ : Digital marketing impact on consumer purchasing power.

H01: $r=0$ : Digital marketing doesn't impact on consumer purchasing power.

2) Ha2: $r \neq 0$ : Consumer purchasing power impact on intention to buy.

H02: $r=0$ : Consumer purchasing power doesn't impact on intention to buy.

3) Ha3: $r \neq 0$ : Digital marketing and consumer purchasing power impact simultaneously on intention to buy.

H03: $r=0$ : Digital marketing and consumer purchasing power doesn't impact simultaneously on intention to buy.

4) Ha4: $r \neq 0$ : Digitalization marketing impact directly on intention to buy.

H04: $r \neq 0$ : Digitalization marketing doesn’t impact directly on intention to buy.

\section{RESULTS AND DISCUSSION}

\section{A. Questionnaire Validity and Reliability}

Table 1. Measured Item Validity Cross-Loadings (Monofactorial Manifest Variables /1)

\begin{tabular}{|l|c|c|c|}
\hline & $\begin{array}{c}\text { Digital } \\
\text { Marketing }\end{array}$ & $\begin{array}{c}\text { Costumer } \\
\text { Purchasing } \\
\text { Power }\end{array}$ & $\begin{array}{c}\text { Invention to } \\
\text { Buy }\end{array}$ \\
\hline Cost & 0.9493 & 0.7993 & 0.7599 \\
\hline $\begin{array}{l}\text { Incentive } \\
\text { Program }\end{array}$ & 0.9433 & 0.7815 & 0.7307 \\
\hline Site Design & 0.961 & 0.7684 & 0.7427 \\
\hline Interactive & 0.9279 & 0.6969 & 0.6766 \\
\hline Income & 0.7075 & 0.8793 & 0.8036 \\
\hline $\begin{array}{l}\text { Housing } \\
\text { Condition }\end{array}$ & 0.7406 & 0.9394 & 0.8308 \\
\hline Education & 0.7395 & 0.9552 & 0.7815 \\
\hline Health & 0.7632 & 0.9477 & 0.8081 \\
\hline Retail Needs & 0.7489 & 0.9566 & 0.785 \\
\hline $\begin{array}{l}\text { Price } \\
\text { Increasing }\end{array}$ & 0.7578 & 0.9353 & 0.8649 \\
\hline $\begin{array}{l}\text { Political } \\
\text { Participation }\end{array}$ & 0.709 & 0.7903 & 0.858 \\
\hline Transactional & 0.709 & 0.7903 & 0.858 \\
\hline
\end{tabular}

\begin{tabular}{|l|l|l|l|}
\hline Preferential & 0.5617 & 0.6777 & 0.8605 \\
\hline Referential & 0.7233 & 0.8279 & 0.9413 \\
\hline $\begin{array}{l}\text { Interest } \\
\text { Exploration }\end{array}$ & 0.6927 & 0.8309 & 0.8497 \\
\hline
\end{tabular}

From Table 1 above, the results of data processing from questionnaires using XLSTAT software indicate the indicator in convergent validity value of each variable has a factor loading more than 0.50 means the statement in the questionnaire valid and can represent the variables of digital marketing, consumer purchasing power and intention to buy in this study, the higher the factor loading the higher the validity.

Table 2. Measured Item Reliability

\begin{tabular}{|l|l|l|}
\hline Latent Variable & Dimensions & Cronbach's alpha \\
\hline Digital Marketing & 4 & 0.9604 \\
\hline $\begin{array}{l}\text { Costumer Purchasing } \\
\text { Power }\end{array}$ & 7 & 0.9675 \\
\hline Intention to Buy & 4 & 0.9006 \\
\hline
\end{tabular}

Source: Questionnaire running by XL Stat 2018

From Table 2 above, the results of data processing from questionnaires using XLSTAT software indicate that construct of each variable has a Cronbach Alpha more than 0.70 means the statement in the questionnaire reliable and can represent the variables of digital marketing, consumer purchasing power and intention to buy in this study.

\section{B. Hypothesis Testing}

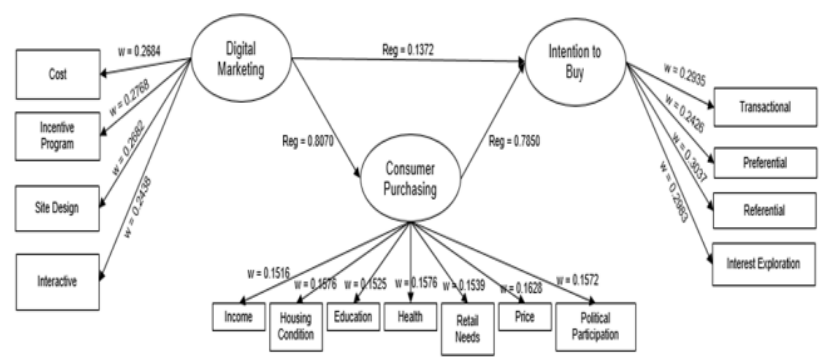

Fig. 2. Hypothesis Test Using PLS Method

Table 3. Inner Model Measure r2 (Consumer Purchasing Power /1)

\begin{tabular}{|c|c|c|c|c|c|c|c|}
\hline $\mathbf{R}^{\mathbf{2}}$ & $\mathbf{F}$ & $\mathbf{P r}>\mathbf{F}$ & $\begin{array}{c}\mathbf{R}^{2} \\
\text { (Bootstr } \\
\text { ap) }\end{array}$ & $\begin{array}{c}\text { Standard } \\
\text { error }\end{array}$ & $\begin{array}{c}\text { Critical } \\
\text { ratio (CR) }\end{array}$ & $\begin{array}{c}\text { Lower } \\
\text { bound } \\
(\mathbf{9 5 \%})\end{array}$ & $\begin{array}{c}\text { Upper } \\
\text { bound } \\
(\mathbf{9 5 \%})\end{array}$ \\
\hline $\mathbf{0 . 6 5 1 3}$ & 184.9 & 0 & 0.6503 & 0.0742 & 8.7756 & 0.4658 & 0.7782 \\
\hline & & & & & & & \\
\hline
\end{tabular}

Table 4. Path Coefficients (Consumer Purchasing Power /1)

\begin{tabular}{|c|c|c|c|c|c|c|}
\hline $\begin{array}{c}\text { Latent } \\
\text { Variable }\end{array}$ & Value & $\begin{array}{c}\text { Standar } \\
\mathrm{d} \text { Error }\end{array}$ & $\mathrm{t}$ & $\mathrm{Pr}>|\mathrm{t}|$ & $\mathrm{f}^{2}$ & $\begin{array}{c}\text { Value } \\
(\text { Bootstra } \\
\mathrm{p})\end{array}$ \\
\hline $\begin{array}{c}\text { Digital } \\
\text { Marketing }\end{array}$ & 0.807 & 0.0593 & 13.6 & 0 & 1.87 & 0.805 \\
\hline
\end{tabular}

Source: Questionnaire running by XL Stat 2018

From Table 3 and 4 above, it can be seen from t statistic $>\mathrm{t}$ table, where $\mathrm{t}$ table for $\mathrm{n}=100$ (df-2) and Alpha 0.05 is 1.985 while $\mathrm{t}$ statistic 13.597 means $\mathrm{H} 0$ is rejected and $\mathrm{Ha} 1$ accepted. For P Value $<0.05$ that is $0.000>0.05$ means a significant variable of

Published By:

Blue Eyes Intelligence Engineering

\& Sciences Publication 
digital marketing impact on consumer purchasing, for the impact magnitude seen in table 2.4 value of $\mathrm{R} 2$ equal to 0.8070 or $80.07 \%$.

Table 5. Inner Model Measure R2 (Intention to Buy/1)

\begin{tabular}{|c|c|c|c|c|c|}
\hline $\mathbf{R}^{\mathbf{2}}$ & $\mathbf{F}$ & Pr $>$ F & $\begin{array}{c}\mathbf{R}^{\mathbf{2}} \\
(\text { Bootstrap })\end{array}$ & $\begin{array}{c}\text { Standard } \\
\text { error }\end{array}$ & $\begin{array}{c}\text { Critical ratio } \\
(\mathbf{C R})\end{array}$ \\
\hline $\mathbf{0 . 8 0 8 8}$ & 207.3 & 0 & 0.807 & 0.0543 & 14.899 \\
\hline
\end{tabular}

Source: Questionnaire running by XL Stat 2018

Table 6. Path Coefficients (Intention to Buy/1)

\begin{tabular}{|c|c|c|c|c|c|}
\hline $\begin{array}{c}\text { Latent } \\
\text { variable }\end{array}$ & Value & $\begin{array}{c}\text { Standard } \\
\text { error }\end{array}$ & $\mathbf{t}$ & $\mathbf{P r}>|\mathbf{t}|$ & $\mathbf{f}^{\mathbf{2}}$ \\
\hline $\begin{array}{c}\text { Digital } \\
\text { Marketing }\end{array}$ & 0.137 & 0.0748 & $\mathbf{1 . 8 3 4}$ & 0.0696 & 0.03 \\
\hline $\begin{array}{c}\text { Consumer } \\
\text { Purchasing } \\
\text { Power }\end{array}$ & 0.785 & 0.0748 & $\mathbf{1 0 . 5}$ & 0 & 1.12 \\
\hline
\end{tabular}

Source: Questionnaire running by XL Stat 2018

Consumer purchasing power simultaneously impact on intention to buy, if $\mathrm{F}$ arithmetic $>$ from $\mathrm{F}$ table, ( $\mathrm{Ho} 3$ is rejected and $\mathrm{Ha} 3$ accepted) then model is significant, for $\mathrm{n}=100$ and $\mathrm{k}=2$ the $\mathrm{t}$ table is 3.09 and $\mathrm{F}$ arithmetic is 207.33, means Ha3 accepted, the model is significant, digital marketing and consumer purchasing power simultaneously impact on intention to buy as much as $80 \%$.

From Table 6, it can be seen from t statistic > t table, where $\mathrm{t}$ table for $\mathrm{n}=100$ (df-2) and Alpha 0.05 is 1.985 while $\mathrm{t}$ statistic for digital marketing 1.834 and 10.495 for consumer purchasing power means:

1) $\mathrm{Ha} 4$ is rejected and $\mathrm{H} 0$ accepted, For $\mathrm{P}$ Value $>0.05$ that is $0.069>0.05$ means model non-significant and $t$ arithmetic $<$ t tabled $(1.8344<1.985)$ means variable of digital marketing doesn't impact directly on intention to buy.

2) $\mathrm{H} 03$ is rejected and Ha3 accepted. $\mathrm{P}$ value $<0.05$ that is $0.0000<0.05$, means model significant and $t$ arithmetic $>\mathrm{t}$ tabled $(10.4956>1.985)$, means consumer purchasing power impact on intention to buy and has direct effect.

3) Equation of the model:

Intention to Buy $=0.13720 *$ Digital

Marketing+0.78498*Consumer Purchasing Power.

Table 7. Direct and Indirect Effect

\begin{tabular}{|c|c|c|c|c|c|}
\hline & \multicolumn{3}{|c|}{ Direct Effect } & \multicolumn{2}{c|}{ Indirect Effect } \\
\cline { 2 - 6 } & $\begin{array}{c}\text { Digital } \\
\text { Marketing }\end{array}$ & $\begin{array}{c}\text { Consumer } \\
\text { Purchasing } \\
\text { Power }\end{array}$ & $\begin{array}{c}\text { Intention } \\
\text { to Buy }\end{array}$ & $\begin{array}{c}\text { Digital } \\
\text { Marketing }\end{array}$ & $\begin{array}{c}\text { Intention } \\
\text { to Buy }\end{array}$ \\
\hline $\begin{array}{c}\text { Digital } \\
\text { Marketing }\end{array}$ & & & & & \\
\hline $\begin{array}{c}\text { Consumer } \\
\text { Purchasing } \\
\text { Power }\end{array}$ & $\mathbf{0 . 8 0 7}$ & & & 0 & \\
\hline $\begin{array}{c}\text { Intention to } \\
\text { Buy }\end{array}$ & $\mathbf{0 . 1 3 7 2}$ & $\mathbf{0 . 7 8 5}$ & & $\mathbf{0 . 6 3 3 5}$ & \\
\hline
\end{tabular}

Source: Questionnaire running by XL Stat 2018

From the table above, this study can prove that variable purchasing power is the intervening variable between digital marketing and intention to buy, digital marketing does not directly affect significantly to intention to buy and require mediation of variable purchasing power.

\section{CONCLUSION}

Consumer purchasing power still plays an important role of a consumer in deciding to buy an item in store-based retail. The rise of digital marketing has an effect on consumer buying interest in store-based retail, it can be said that online store that gives a good digital campaign will be able to make store-based retail less visitors, therefore make promotion campaign with consideration of purchasing power is important, need to be seen income sensitivity, the feasibility of occupancy, health, political activity, retail shopping needs in making a digital marketing campaign in retail store-based, the main suggestion is price discount adjustment using health insurance membership card such as BPJS, because having health insurance (BPJS) is mandatory for Indonesian citizens then their chances of using this type of discount is bigger or political party worth trying to build buying interest and uniqueness.

\section{CONFLICT OF INTEREST}

The authors certify that they have NO affiliations with or involvement in any organization or entity, with any financial interest (such as honoraria; educational grants; participation in speakers' bureaus; membership, employment, consultancies, stock ownership, or other equity interest; and expert testimony or patent-licensing arrangements), or nonfinancial interest (such as personal or professional relationships, affiliations, knowledge or beliefs) in the subject matter or materials discussed in this manuscript.

\section{ACKNOWLEDGMENT}

Our acknowledgment goes to Unibi and Universitas Widyatama for the support.

\section{REFERENCES}

1. P. Anoraga. Manajemen Bisnis. Jakarta: Rineka Cipta, 2000.

2. C. A. Mallin. Handbook on international corporate governance: country analyses. Cheltenham: Edward Elgar Publishing, 2011.

3. N. K. Hidayat and R. Tobing. "Enhancing netizen as a digital marketing activity toward strategic branding: a case study of "xyz" brand." Jurnal the Winners, vol. 13, no. 1, pp. 58-65, 2012.

4. Meyliana. "Analisis Strategi E-Marketing dan Implementasi pada Rental.” Jakarta: Company Publisher, 2011.

5. S. Pawenang. Modul Perkuliahan Lingkungan Ekonomi Bisnis. Surakarta: Program Pascasarjana UNIBA.

6. S. Arief. Indonesia: Growth, Income Disparity, and Mass Poverty. Jakarta: Sritua Arief Associates, 1977.

7. D. Salvator. International Economics. Britania Raya: MacMillan, 1990.

8. P. Smith, Flower and M. Larkin. Interpretative Phenomenological Analysis: Theory, Method. London: Sage Publisher, 2009.

9. S. McCoy, A. Everard, P. Polak, and D. F. Galletta. "The Effects of Online Advertising." Communications ofthe ACM, vol. 50, no. 3, pp. 84-88, 2007. 
The Impact of Digitalization of Marketing and Consumer Purchasing Power as an Intervening Towards Intention to Buy Product in Store-Based Retail Store

10. P. Chatterjee, "Online Reviews: Do Consumers Use Them?." Advances in Consumer Research, vol.28, no.1, pp.129-33, 2001.

11. E. Y. Kim and Y. Kim. "Predicting Online Purchase Intentions for Clothing Products Null." European Journal of Marketing, vol. 38, no. 7, pp. 883-897, 2011.

12. C. W. Lamb, J. F. Hair and C. McDaniel. Essentials of marketing. Boston: Cengage Learning, 2011.

13. J. Dodd and B. Kent, Monroe and P Grewal. "The Evaluating of Price, Perceived Quality, and Customer Perceptions of Products Quality." Journal of Marketing Research, vol. 42, pp. 331-349, 1991.

14. P. Anoraga. Manajemen Bisnis. Jakarta: Rineka Cipta, 2000

15. H. Assael. Consumer Behavior and Marketing Action. Boston: PWS-Kent Publishing Company, 2002.

16. L. Hakim and N. Susianti. "Influence of Customer Relationship Management, Brand Equity,Perceived Product Quality, Perceived Price on Customer Value and Purchase Intention (Studies Philips Light Bulb in Batam)." International Journal of Economics and Finance; vol. 9, no. 7, pp. 122-131, 2017.

17. J. Wirdatul "Pengaruh Penurunan Harga Karet Mentah Terhadap Daya Beli Masyarakat Di Pasar Desa. Pasir Jaya”. Vol 7, No 2 (2018): Jurnal Ilmiah Cano Ekonomos

18. G. Wahyutyasto and S. Wibowo. "Pengaruh Mobile Marketing Terhadap Minat Beli Konsumen (studi Pada California Fried Chicken (cfc) Store Universitas Telkom Bandung)." eProceedings of Management, vol. 4, no. 1, pp. 735-744, 2017.

19. W. Wiyadi, N. Amalina, R. Trisnawati and N. Sasongko. "Perspektif Positif Praktik Manajemen Laba: Kajian Empiris Pada Perusahaan Manufaktur Go Publik Di Bursa Efek Indonesia." Riset Akuntansi dan Keuangan Indonesia, vol. 2, no. 1, pp. 49-60.I

20. K. N. Malhotra, Review of Marketing Research, Bingley: Emerald Group Publishing Limited, 2007.

21. W. Abdillah and J. Hartono. Partial Least Square (PLS) - Alternative Structural Equation Modelling (SEM) in Business Research. Yogyakarta: Andi Publisher, 2015 